\title{
Comparison of D-dimer Level Measured on the Third Day of Hospitalization with Admission D-dimer Level in Predicting In-hospital Mortality in COVID-19 Patients
}

\author{
COVID-19 Hastalarında Hastane İçi Mortaliteyi Öngörmede Hastaneye \\ Yatışının Üçüncü Gününde Ölçülen D-Dimer Düzeyinin Kabul D-Dimer \\ Düzeyi ile Karşılaştırılması
}

\author{
Murat SELCUK ๑, Tufan CINAR ๑, Nuran GUNAY $\odot$, Muhammed KESKIN $\odot$, Vedat CICEK $\odot$ \\ Sahhan KILIC ${ }^{\oplus}$, Süha ASAL ${ }^{\oplus}$, Ahmet L. ORHAN $\odot$
}

Ethics Committee Approval: This study approved by the Umraniye Training and Research Hospital Clinical Research Ethics Committee, 12 May 2020, 150.

Conflict of interest: The authors declare that they have no conflict of interest.

Funding: None.

Informed Consent: Inform consent was not necessary because the study had a retrospective design.
Cite as: Selcuk M, Cinar T, Gunay N, et al. Comparison of D-dimer level measured on the third day of hospitalization with admission D-dimer level in predicting in-hospital mortality in COVID-19 patients. Medeni Med J. 2021;36:1-6.

\begin{abstract}
Objective: The present study aimed to compare the value of D-dimer measured on the 3rd day of hospitalization with admission D-dimer level in predicting in-hospital mortality in coronavirus disease 2019 (COVID-19) cases.

Method: In total, 231 patients with COVID-19 disease were included in the study. D-dimer levels were estimated using immunoturbidimetric assay with normal range of 0-500 $\mu \mathrm{g} / \mathrm{mL}$. In the current research, the primary outcome was the in-hospital mortality.

Results: In the present research, 39 (16.8\%) COVID-19 cases died during the index hospitalization. In a multivariable analysis; age, D-dimer (3'd day) (OR: 1.00, 95\% Cl: 1.00-1.00, $p<0.001)$. WBC count, and creatinine were independent predictors of the in-hospital death for COVID-19 cases. The ideal value of D-dimer level on the $3^{\text {rd }}$ day of hospitalization was $774 \mu \mathrm{q} / \mathrm{mL}$ (area under curve (AUC): $0.903,95 \% \mathrm{Cl}: 0.836-0.968 ; p<0.01$ ) with sensitivity of $83.2 \%$ and specificity of $83.6 \%$. It was noted that D-dimer level on the $3^{\text {rd }}$ day of hospitalization had a higher sensitivity (83.2\% vs $67.6 \%$, respectively) and AUC value than that of D-dimer level on admission ( 0.903 vs 0.799 , respectively).

Conclusion: The main finding in this investigation was that D-dimer elevation on the $3^{\text {rd }}$ of hospitalization is more sensitive predictor of in-hospital mortality than D-dimer elevation on admission in COVID-19 patients. Even though further investigations are needed to forecast precise prognosis in patients with COVID-19 disease in terms of D-dimer levels, we believe that D-dimer levels on the $3^{\text {rd }}$ day of hospitalization have an enhanced potential to be used as a prognostic marker in routine clinical practice.
\end{abstract}

Keywords: COVID-19, D-dimer, $3^{\text {rd }}$ day of hospitalization, admission

öz

Amaç: Bu çalışma, koronavirüs hastalı̆̆ı 2019 (COVID-19) hastalarında hastane içi mortaliteyi öngörmede 3. gün hastanede ölçülen D-dimer değeri ile başvuru D-dimer düzeyini karşılaştırmayı amaçlamaktadır. Yöntem: Toplamda, COVID-19'lu 231 hasta çalıșmaya dâhil edildi. D-dimer seviyeleri, O-500 $\mu \mathrm{q} / \mathrm{mL}$ normal aralığı ile immünoturbidimetrik test kullanılarak ölçüldü. Mevcut araştırmada, birincil sonlanım hastane içi tüm nedenlere bağlı mortaliteydi.

Bulgular: Mevcut araştırmada, 39 (\%16,8) COVID-19 vakası hastanede yatarken öldü. Çok değişkenli analizde; yas, D-dimer (3. ̈̈ncü gün) (OR: 1.00, \%95 Cl: 1.00-1.00, p<0.001), beyaz küre sayısı ve kreatinin, COVID-19 vakaları için hastane içi ölümün bağımsız prediktörleri idi. Hastaneye yatısın 3'üncü gününde bakılan D-dimer seviyesi \%83,2 duyarllık ve \%83,6 özgüllük ile ideal değeri $774 \mu \mathrm{q} / \mathrm{mL}$ 'di (eğri altındaki alan (AUC): 0.903,\%95 GA: 0,836-0.968; $p<0.01$ ). Hastaneye yatısın 3 'üncü günündeki $D$-dimer düzeyinin, bașvurdaki $D$-dimer düzeyinden daha yüksek duyarlılı̆a (sırasıyla \%83,2'ye karşı \%67,6) ve AUC değerine (sırasılyla 0,903'e karşı 0,799) sahip olduğu saptandı.

Sonuc: Bu araștırmadaki temel bulgu, COVID-19 hastalarında hastaneye yatısısnın 3'üncü günündeki D-dimer yükselmesinin, hastaneye başvuru sırasındaki D-dimer seviyesine göre hastane içi mortalitenin daha duyarlı bir prediktörü olmasıdır. COVID-19 hastalığı olan hastalarda D-dimer düzeyi açııından kesin prognozu tahmin etmek için daha fazla araştırmaya ihtiyaç duyulsa da, 3. gün yatışstaki D-dimer düzeyinin rutinde prognostik bir belirteç olarak kullanılma potansiyeline sahip olduğunu düşünmekteyiz.

Anahtar kelimeler: COVID-19, D-dimer, 3. gün hastanede yatış, başvuru
Received: 24 December 2020

Accepted: 27 February 2021

Online First: 26 March 2021

Corresponding Author: T. Cinar

ORCID: 0000-0001-8188-5020 Health Sciences University,

Sultan Abdülhamid Han

Training and Research Hospital, Department of Cardiology, Istanbul, Turkey

drtufancinar@gmail.com

M. Selcuk

ORCID: 0000-0002-6386-0142

M. Keskin

ORCID: 0000-0002-4938-0097

V. Cicek

ORCID: 0000-0002-3763-0570

S. Kilic

ORCID: 0000-0002-3524-5396

S. Asal

ORCID: 0000-0002-3709-2506

A.L. Orhan

ORCID: 0000-0002-8617-3281

Health Sciences University,

Sultan Abdülhamid Han

Training and Research Hospital,

Department of Cardiology, Istanbul, Turkey

N. Gunay

ORCID: 0000-0003-3779-6957

Health Sciences University,

Ümraniye Training and Research Hospital,

Department of Cardiology, Istanbul, Turkey

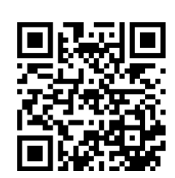




\section{INTRODUCTION}

The outbreak of COVID-19 (coronavirus disease 2019) caused by SARS-CoV-2 (acute respiratory syndrome coronavirus-2) is a continuing global health crisis ${ }^{1}$. Since the beginning of the pandemic, the virus had infected approximately 70 million people, causing more than 1,630,000 deaths worldwide ${ }^{2}$. Current data indicates that most patients who have poor outcomes due to COVID-19 infection have higher incidence of disseminated intravascular coagulopathy, acute pulmonary embolism, and also multiple organ failure ${ }^{3}$. Therefore, D-dimer levels are usually found higher among these cases. Currently, several studies have investigated the prognostic significance of admission D-dimer for in-hospital mortality in COVID-19 cases $^{4-6}$. These studies consistently found that elevated D-dimer values upon admission were related with higher in-hospital death in these cases. However, it was also observed that, D-dimer levels were usually elevated during hospitalization, especially in subjects with serious COVID-19 infection compared to those with milder forms as the infection progress ${ }^{7}$. Hence, it is unknown whether D-dimer levels measured on the third day of hospitalization may have higher predictive value than admission D-dimer levels for in-hospital mortality in COVID-19 cases. According to this data, the present research aimed to compare the value of D-dimer measured on the third day hospitalization with admission D-dimer level to predict inhospital death in COVID-19 cases.

\section{MATERIAL and METHODS}

\section{Study cohort}

This retrospective study has an observational design. In all cases, COVID-19 infection was confirmed according to SARS-CoV-2 RNA detection in a nasopharyngeal swab by RT-PCR. Also, most cases in the study had the typical ground-glass infiltrates in the chest computed tomography, which were attributable to COVID-19 disease. For each case enrolled in the study, baseline demographic features, comorbidities, and laboratory data were retrieved from hospital electronic database. We also noted previous medications of all patients. Patients with missing clinical information were excluded from the research. In addition, COVID19 with recently acute coronary syndrome, malignancy, and acute renal and hepatic failure were excluded. Besides that, patients in whom D-dimer levels were not measured on the third day of hospitalization were excluded. In total, 231 patients with COVID-19 infection were enrolled in this retrospective research. The treatment strategies of the cases were left to the discretion of the attending physicians and planned in accordance with the COVID-19 pandemic guidelines of the Ministry of Health. After obtaining an approval from the Scientific Research COVID-19 Committee, our research was then reviewed and approved by the Local Ethics Committee of the Ministry of Health (approval number: B.10.1.TKH.4.34.H.GPO.01/150). The current research was performed based on the "Good Clinical Practice" guidelines of the Declaration of Helsinki. Informed consent was not necessary because the study had a retrospective design.

\section{Laboratory analysis}

All blood specimens were analyzed as for C-reactive protein, D-dimer, biochemical and hematologic parameters during index hospitalization. D-dimer levels were measured using immunoturbidimetric assay with normal range of 0-500 $\mu \mathrm{q} /$ $\mathrm{mL}$. Complete blood count parameters were analyzed using the Sysmex XN 9000 hematology analyzers (Kobe, Japan). By using Beckman Coulter kits and calibrators, all biochemical analyses were performed.

\section{Study outcome}

In the current research, the primary outcome was the in-hospital death. An experienced study coordinator assessed the medical records of each case and verified the in-hospital mortality. 


\section{Statistical analysis}

All statistical analyses were done using SPSS software (IBM, Version 21.0). The number of cases and percentages were calculated for categorical variables, while the data was displayed as mean \pm SD for continuous parameters. In order to test the normal distribution assumption for continuous variables, the Kolmogorov-Smirnov test was utilized. Descriptive parameters were compared using chi-square test or Fisher's exact test. The Mann-Whitney $U$ test or unpaired t-test, as appropriate, was performed to assess the quantitative data. Both univariate and multivariate LR (logistic regression) analyse were applied to determine independent parameters of in-hospital mortality. After performing univariate analysis, variables with $\mathrm{p}<0.05$ significance level were selected for the multivariate LR analysis. The OR (odds ratio) with $95 \% \mathrm{Cl}$ (confidence intervals) was used to present the results of univariate and multivariate $L R$ analyses. The ideal value of D-dimer levels on admission and on the third day of hospitalization for in-hospital mortality was assessed using receiver operating curve (ROC) analysis. For each comparison, we accepted the statistical significance level as $p$ value below $<0.05$.

\section{RESULTS}

The mean age of COVID- 19 patients was 60 years;

Table 1 Characteristics of survivor and non-survivor patients hospitalized with the diagnosis of COVID-19 pneumonia.

\begin{tabular}{|c|c|c|c|}
\hline & $\begin{array}{l}\text { Survivor } \\
(n=192)\end{array}$ & $\begin{array}{l}\text { Non-Survivor } \\
(\mathrm{n}=39)\end{array}$ & P value \\
\hline \multicolumn{4}{|l|}{ Characteristics } \\
\hline Age Mean \pm SD & $52 \pm 14$ & $68 \pm 13$ & $<0.001$ \\
\hline \multicolumn{4}{|l|}{ Gender, n (\%) } \\
\hline Male & 103 (53.6) & $26(66.7)$ & \multirow[t]{2}{*}{0.135} \\
\hline Female & $89(46.4)$ & $103(53.6)$ & \\
\hline \multicolumn{4}{|l|}{ Comorbidities, n (\%) } \\
\hline Hypertension & $58(30.2)$ & $24(61.5)$ & $<0.001$ \\
\hline Diabetes mellitus & $43(22.4)$ & $15(38.5)$ & 0.035 \\
\hline Smoking & $16(8.3)$ & $4(10.3)$ & 0.697 \\
\hline Chronic lung disease & $21(10.9)$ & $8(20.5)$ & 0.100 \\
\hline Chronic kidney disease & $10(5.2)$ & $6(15.4)$ & 0.022 \\
\hline Coronary artery disease & $16(8.3)$ & $14(35.9)$ & $<0.001$ \\
\hline Heart failure & $4(2.1)$ & $5(12.8)$ & 0.002 \\
\hline Stroke & $4(2.1)$ & $2(5.1)$ & 0.276 \\
\hline Dementia & $0(0.0)$ & $3(7.7)$ & $<0.001$ \\
\hline Cancer & $3(3.1)$ & $3(7.7)$ & 0.179 \\
\hline \multicolumn{4}{|l|}{ Medications, n (\%) } \\
\hline Aspirin & $20(10.4)$ & $16(41.0)$ & $<0.001$ \\
\hline Anticoagulant therapy & $3(1.6)$ & $2(5.1)$ & 0.163 \\
\hline Statins & $11(5.7)$ & $10(25.6)$ & $<0.001$ \\
\hline Insulin & $11(5.7)$ & $10(25.6)$ & $<0.001$ \\
\hline \multicolumn{4}{|l|}{ Laboratory data } \\
\hline White blood cell count, cells $/ \mu \mathrm{L}($ mean \pm SD) & $5.87 \pm 2.45$ & $9.26 \pm 4.88$ & 0.004 \\
\hline Neutrophils, (mean \pm SD) & $3.85 \pm 2.11$ & $7.60 \pm 4.80$ & $<0.001$ \\
\hline Lymphocytes $/ \mu \mathrm{L}($ mean $\pm \mathrm{SD})$ & $1.48 \pm 0.70$ & $1.10 \pm 0.69$ & 0.002 \\
\hline Platelets, cells $/ \mu \mathrm{L}($ mean $\pm \mathrm{SD})$ & $204 \pm 64$ & $230 \pm 81$ & 0.031 \\
\hline Hemoglobin, g/dL (mean \pm SD) & $13.1 \pm 1.8$ & $12.1 \pm 2.7$ & 0.004 \\
\hline Glucose, mg/dL (mean \pm SD) & $116 \pm 46$ & $163 \pm 96$ & $<0.001$ \\
\hline Fibrinogen, mg/L (mean \pm SD) & $565 \pm 180$ & $490 \pm 220$ & 0.145 \\
\hline D-dimer (admission), $\mu \mathrm{g} / \mathrm{mL}$ (mean $\pm \mathrm{SD}$ ) & $539 \pm 520$ & $1706 \pm 1532$ & $<0.001$ \\
\hline D-dimer (3rd day), $\mu \mathrm{g} / \mathrm{mL}($ mean $\pm \mathrm{SD})$ & $541 \pm 540$ & $2053 \pm 1750$ & $<0.001$ \\
\hline C-reactive protein, $\mathrm{mg} / \mathrm{dL}($ mean $\pm \mathrm{SD})$ & $58.2 \pm 63.3$ & $46.9 \pm 68.8$ & 0.320 \\
\hline Alanine aminotransferase, U/L (mean \pm SD) & $36 \pm 33$ & $36 \pm 35$ & 0.936 \\
\hline Aspartate aminotransferase, $\mathrm{U} / \mathrm{L}($ mean $\pm \mathrm{SD})$ & $31 \pm 24$ & $74 \pm 167$ & 0.001 \\
\hline Creatinine, $\mathrm{mg} / \mathrm{dL}($ meanMean $\pm \mathrm{SD})$ & $0.95 \pm 0.24$ & $1.38 \pm 0.77$ & $<0.001$ \\
\hline Hospital stay, d (meanMean \pm SD) & $7 \pm 4$ & $11 \pm 7$ & $<0.001$ \\
\hline
\end{tabular}


Table 2 Univariate analysis and multivariate model for in-hospital mortality.

\begin{tabular}{lrclcc}
\hline Univariate analysis & P value & OR $(\mathbf{9 5} \% \mathbf{C I})$ & Multivariate analysis & P value & OR (95\% CI) \\
\hline Age & $<0.001$ & $1.09(1.06-1.13)$ & Age & 0.001 & $1.07(1.03-1.11)$ \\
Hypertension & $<0.001$ & $3.69(1.80-7.55)$ & - & - & - \\
Diabetes mellitus & 0.038 & $2.11(1.04-4.48)$ & - & - & - \\
Chronic kidney disease & 0.030 & $3.30(1.12-9.72)$ & - & - \\
Coronary artery disease & $<0.001$ & $6.16(2.68-14.13)$ & - & - \\
D-dimer (3rd day) & $<0.001$ & $1.00(1.00-1.00)$ & D-dimer (3rd day) & $<0.001$ & $1.00(1.00-1.00)$ \\
White blood cell & $<0.001$ & $1.30(1.17-1.45)$ & White blood cell & 0.008 & $1.21(1.05-1.40)$ \\
Hemoglobin & 0.009 & $0.81(0.70-0.95)$ & - & - \\
Platelet & 0.034 & $1.00(1.00-1.00)$ & - & - \\
Creatinine & $<0.001$ & $19.22(5.46-67.68)$ & Creatinine & - \\
Glucose & $<0.001$ & $1.01(1.00-1.01)$ & - & 0.040 & $3.59(0.98-14.66)$ \\
& & & & -
\end{tabular}

All clinically relevant parameters were included in the model. Abbreviations; OR, Odds ratio; $\mathrm{Cl}$, confidence interval.

$55.8 \%$ of them were males, and the most observed comorbidities were hypertension (HT) in 35.4\%, diabetes mellitus (DM) in $25.1 \%$ and coronary artery disease (CAD) in $12.9 \%$ of the patients (Table 1). In the present research, 39 (16.8\%) COVID-19 cases died during the index hospitalization. We classified the study cohort into survivor and nonsurvivor groups. We observed that the prevalence rates were significantly higher in the non-survivor vs survivor group as follows: HT [66.7\%; n:26 vs 30.2\%; n:56)], DM [38.5\%; n:15 vs 22.4\%; n:43)], chronic kidney disease [15.4\%; n:6 vs 5.2\%; n:10)], CAD [35.9\%; n:14 vs 8.3\%; n:16)], heart failure [12.8\%; n:5 vs 2.1\%; n:4)], and dementia [7.7\%; n:3 vs $0.0 \% ; n: 0)]$ The frequency of previous medication use was also higher in the nonsurvivor vs survivor group during the index hospitalization as follows: aspirin [41.0\%; n:16 vs 10.4\%; n:20)], statin [25.6\%; n: 10 vs 5.7\%; n: 11$]$, and insulin [25.6\%; $\mathrm{n}: 10$ vs $5.7 \% ; n=11)]$. Comparison of laboratory results demonstrated that white blood cell (WBC), neutrophil, and platelet counts, glucose, D-dimer levels on admission, D-dimer levels on the third day of hospitalization, aspartate aminotransferase, and creatinine levels were higher; but lymphocyte counts and hemoglobin levels were lower in the non-survivor group. As expected, patients who died had longer days of hospitalization.

As shown in Table 2, both univariate and multivariate LR analyses were performed to deter-

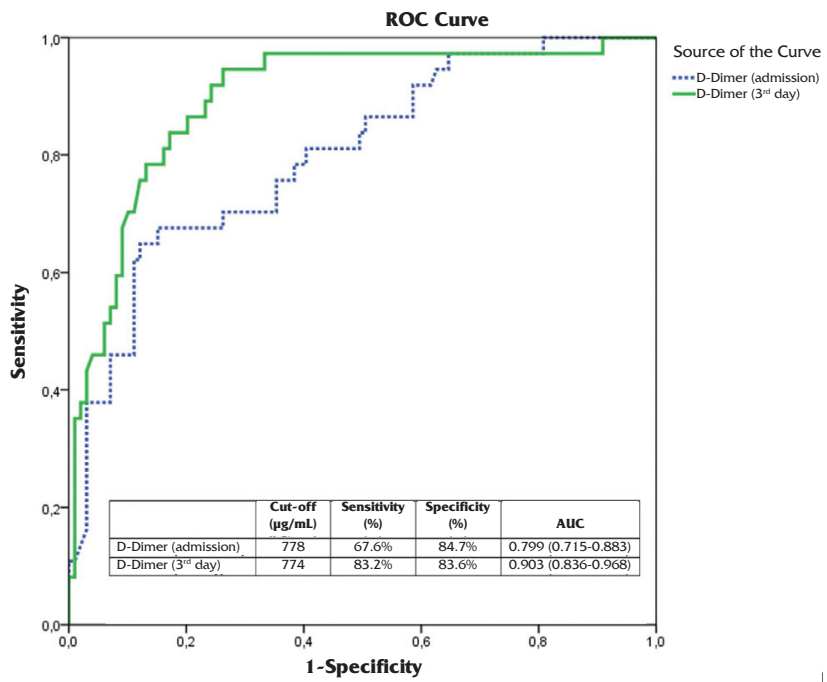

Figure 1. A receiver operating curve analysis comparison for area under curve values of D-dimer levels on admission and on the $3^{\text {rd }}$ day of hospitalization.

mine the independent predictors of in-hospital mortality (Table 2). By using the backward LR method, all parameters found significant in univariate analyses, including age, HT, DM, chronic kidney disease, CAD, D-dimer (third day), WBC, and platelet counts, hemoglobin, creatinine, and glucose, were entered into multivariate analysis. In this analysis; age (OR: 1.07, 95\% CI: 1.03-1.11, $\mathrm{p}=0.001$ ), D-dimer (third day) (OR: $1.00,95 \% \mathrm{Cl}$ : 1.00-1.00, $\mathrm{p}<0.001$ ), WBC count (OR: 1.21, 95\% CI: 1.05-1.40, $p=0.008$ ), and creatinine (OR: 3.59, 95\% CI: 0.98-14.66, $\mathrm{p}=0.040$ ), were found independently related with the in-hospital mortality in COVID-19 cases. 
In the ROC evaluation, the ideal value of D-dimer level on admission in predicting in-hospital mortality was $778 \mu \mathrm{g} / \mathrm{mL}$ (area under curve (AUC): 0.799, 95\% Cl: 0.715-0.883; $\mathrm{p}<0.01$ ) with sensitivity of $67.6 \%$ and specificity of $84.7 \%$ and the ideal value of $\mathrm{D}$-dimer level on the third day of hospitalization was $774 \mu \mathrm{q} / \mathrm{mL}$ (area under curve (AUC): 0.903, 95\% CI: 0.836-0.968; $\mathrm{p}<0.01$ ) with sensitivity of $83.2 \%$ and specificity of $83.6 \%$ (Figure 1). It was noted that D-dimer level on the $3^{\text {rd }}$ day of hospitalization had a higher sensitivity and AUC value than D-dimer level on admission.

\section{DISCUSSION}

The main finding in the study was that D-dimer elevation on the third day of hospitalization was more sensitive predictor of in-hospital mortality than D-dimer elevation on admission in COVID19 patients. According to the results of the study, we considered that D-dimer level on the third day of hospitalization to predict mortality in these cases in addition to the measurement of D-dimer level on admission.

Current findings suggest that elevated D-dimer levels represent a hypercoagulable status in COVID19 cases, which might be due to several reasons. First of all, viral infections can induce development of an uncontrolled inflammatory response and poor anti-inflammatory response control in the body $^{8}$. Moreover, such infections can cause endothelial cell dysfunction, resulting in the production of excess thrombin 9 . Secondly, the hypoxia present in severe forms of COVID-19 subjects can induce thrombosis by either increasing blood viscosity or increasing the signaling pathway via the hypoxia-inducible transcription factor ${ }^{10,11}$. Thirdly, hospitalized COVID-19 patients are likely to be elderly people with chronic illnesses needing longterm bed rest, both of which were risk factors for thrombosis and hypercoagulation ${ }^{12-14}$. In fact, occlusion and development of microthrombosis in small lung vessels were demonstrated in critical patients with COVID-19 ${ }^{15}$. Lastly, most patients can experience coagulopathy caused by sepsis or disseminated intravascular coagulation ${ }^{15,16}$.

Current evidence indicates that in COVID-19 cases, D-dimer levels are often elevated and also higher in subjects with severe COVID-19 disease than in those with milder types. In a descriptive study of 99 COVID-19 cases in Wuhan, China, elevated D-dimer levels were thus observed in 36\% of the patients ${ }^{17}$. Furthermore, Huang et al. ${ }^{4}$ recorded clinical and laboratory laboratory results in 41 patients hospitalized with confirmed COVID19 and their D-dimer levels were five times higher in those with serious disease than in those without. Also, Zhou et al. ${ }^{5}$ analyzed 191 COVID-19 patients and found that $\mathrm{D}$-dimer values among patients who died were found nearly nine times higher than in those who survived. Remarkably, data from 343 patients registered with COVID19 disease in Wuhan were collected by Zhang et al. ${ }^{6}$ and they reported that patients with D-dimer $>2000 \mathrm{ng} / \mathrm{ml}$ demonstrated higher mortality rates than those with D-dimer $<2000 \mathrm{ng} / \mathrm{ml}$. However, all above-mentioned studies mainly investigated the prognostic significance of D-dimer level on admission for in-hospital mortality in COVID-19 cases. It was well-recognized, D-dimer levels typically increase during hospitalization as the infection progress, particularly in severe COVID19 cases compared to those with milder forms. Therefore, it remains unknown whether D-dimer levels measured on the third day of hospitalization may have higher prognostic value than admission D-dimer levels for in-hospital mortality in COVID19 cases. In fact, our findings demonstrated that D-dimer levels measured on the third day of hospitalization had higher sensitivity for the prediction of in-hospital mortality in COVID-19 cases. Moreover, it was clearly shown that AUC value of D-dimer levels on the third day of hospitalization was significantly higher than that of D-dimer level on admission ( 0.903 vs 0.799 , respectively). Even though further investigations are needed to forecast precise prognosis in COVID-19 cases in terms of D-dimer levels, we believe that D-dimer 
levels measured on the third day of hospitalization have an enhanced potential to be used as a prognostic marker in routine clinical practice.

\section{Limitations}

The study has some limitations. Our results were based on the retrospective design of the study, which might include selection bias despite the fact that consecutive COVID-19 cases were included in the analyses. Another important limitation was that the sample size of the study was relatively small. However, it should be acknowledged that COVID-19 infection is usually mild in most patients. Therefore, such patients are not generally hospitalized. Our research was performed in geographical area; thus, this might limit the generalizability of the findings of the study to other geographic regions. We acknowledged that there might be the some residual confounding variables, all of which might ultimately affect the final outcome. Lastly, further prospective studies enrolling greater number of participants are needed to verify the findings of this study.

\section{CONCLUSION}

In this research, we found that elevated D-dimer levels on the third day of hospitalization were related with higher mortality in COVID-19 patients. In addition, predictive power of D-dimer level on the $3^{\text {rd }}$ day of hospitalization was substantially higher than D-dimer level on admission for in-hospital mortality among COVID-19 cases. As a result, the D-dimer level on the third day of hospitalization appears to have a substantial role to predict in-hospital mortality among COVID-19 patients.

\section{REFERENCES}

1. Sohrabi C, Alsafi Z, O’Neill N, et al. World Health Organization declares global emergency: A review of the 2019 novel coronavirus (COVID-19). Int J Surg. 2020;76:71-6. [CrossRef]

2. World Health Organization. World Health Organization (WHO) Coronavirus Disease (COVID-19) Dashboard [cited 2020 May 29]. Available from: https://covid19.who. int/

3. Kakodkar P, Kaka N, Baig MN. A comprehensive literature review on the clinical presentation, and management of the pandemic coronavirus disease 2019 (COVID19). Cureus. 2020;12:e7560. [CrossRef]

4. Huang C, Wang Y, Li X, et al. Clinical features of patients infected with 2019 novel coronavirus in Wuhan, China. Lancet. 2020;395:497-506. [CrossRef]

5. Zhou F, Yu T, Du R, et al. Clinical course and risk factors for mortality of adult inpatients with COVID-19 in Wuhan, China: a retrospective cohort study. Lancet. 2020;395:1054-62. [CrossRef]

6. Zhang L, Yan X, Fan Q, et al. D-dimer levels on admission to predict in-hospital mortality in patients with Covid-19. J Thromb Haemost. 2020;18:1324-9. [CrossRef]

7. Oualim S, Abdeladim S, Ouarradi AE, et al. Elevated levels of D-dimer in patients with COVID-19: prognosis value. Pan Afr Med J. 2020;35:105. [CrossRef]

8. Wong JP, Viswanathan S, Wang M, Sun LQ, Clark GC, D'Elia RV. Current and future developments in the treatment of virus-induced hypercytokinemia. Future Med Chem. 2017;9:169-78. [CrossRef]

9. Levi M, van der Poll T. Coagulation and sepsis. Thromb Res. 2017;149:38-44. [CrossRef]

10. Gupta N, Zhao YY, Evans CE. The stimulation of thrombosis by hypoxia. Thromb Res. 2019;181:77-83. [CrossRef]

11. Tang N, Bai H, Chen X, Gong J, Li D, Sun Z. Anticoagulant treatment is associated with decreased mortality in severe coronavirus disease 2019 patients with coagulopathy. J Thromb Haemost. 2020;18:1094-9. [CrossRef]

12. Harper PL, Theakston E, Ahmed J, Ockelford P. D-dimer concentration increases with age reducing the clinical value of the D-dimer assay in the elderly. Intern Med J. 2007;37:607-13. [CrossRef]

13. Barbar S, Noventa F, Rossetto V, et al. A risk assessment model for the identification of hospitalized medical patients at risk for venous thromboembolism: the Padua Prediction Score. J Thromb Haemost. 2010;8:2450-7. [CrossRef]

14. Hess K, Grant PJ. Inflammation and thrombosis in diabetes. Thromb Haemost. 2011;105(Suppl 1):S43-54. [CrossRef]

15. Tang N, Li D, Wang X, Sun Z. Abnormal coagulation parameters are associated with poor prognosis in patients with novel coronavirus pneumonia. J Thromb Haemost. 2020;18:844-7. [CrossRef]

16. Iba T, Levy JH, Warkentin TE, et al. Diagnosis and management of sepsis-induced coagulopathy and disseminated intravascular coagulation. J Thromb Haemost. 2019;17:1989-94. [CrossRef]

17. Chen N, Zhou M, Dong X, et al. Epidemiological and clinical characteristics of 99 cases of 2019 novel coronavirus pneumonia in Wuhan, China: a descriptive study. Lancet. 2020;395:507-13. [CrossRef] 